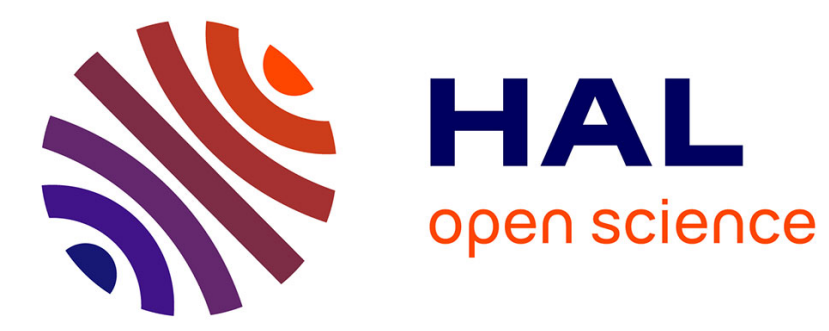

\title{
Performance of nonwoven geotextiles on soil drainage and filtration
}

Nour-Eddine Sabiri, Adeline Caylet, Agnès Montillet, Laurence Le Coq, Yves Durkheim

\section{- To cite this version:}

Nour-Eddine Sabiri, Adeline Caylet, Agnès Montillet, Laurence Le Coq, Yves Durkheim. Performance of nonwoven geotextiles on soil drainage and filtration. European Journal of Environmental and Civil Engineering, 2017, 10.1080/19648189.2017.1415982 . hal-01741182

\section{HAL Id: hal-01741182 \\ https://hal.science/hal-01741182}

Submitted on 21 Aug 2019

HAL is a multi-disciplinary open access archive for the deposit and dissemination of scientific research documents, whether they are published or not. The documents may come from teaching and research institutions in France or abroad, or from public or private research centers.
L'archive ouverte pluridisciplinaire HAL, est destinée au dépôt et à la diffusion de documents scientifiques de niveau recherche, publiés ou non, émanant des établissements d'enseignement et de recherche français ou étrangers, des laboratoires publics ou privés. 


\title{
Performance of nonwoven geotextiles on soil drainage and filtration
}

\author{
Nour-Eddine Sabipi, Adeline Caylett, Agnès Montillę, Laurence Le Cợand \\ Yves Durkheinq
}

auniversité de nantes, gEpEa, umr-CnrS 6144, nantes, france; $\quad$ buniversité de Bretagne Sud, frE CnrS 3744, irdl, pontivy, france; 'afitEX, Champhol, france

\begin{abstract}
The selection of a geotextile to prevent the soil suffusion in a civil engineering work is a classical problem. The internal erosion is a key factor as the migration of fine particles damages the integrity of the soil structure. This work deals with the problem of using a draining system consisting of a layer of soil and a geotextile sheet in order to prevent soil suffusion. It proposes a methodology which allows ordering the performance of nonwoven geotextiles. A range of experimental approaches were implemented including seepage flow tests under controlled flow rates. A detailed analysis of the data shows that intrinsic properties of geotextiles are not sufficient to predict their behaviour in a draining system. Moreover, the classical flow tests of the draining systems are not sufficient to adequately discriminate the three geotextile specimen used here. On the other hand, it seems important to use the history of the hydraulic gradient with respect to the flow rate variation. Thus, the present data of normalised relative pressure drop and normalised relative variation of flow rate are arranged in terms of a dimensionless criterion. This methodology enables evaluating and discriminating the performances of the geotextiles used here in terms of filtration and drainage functions.
\end{abstract}

ARTICLE HISTORY

received 8 march 2017 accepted 6 december 2017

\section{KEYWORDS}

geotextile; filtration; drainage; efficiency; porous media and structural parameters

\section{Introduction}

Synthetic geotextiles (GT) manufactured from polypropylene, polyester, polyamides or polyethylene have been extensively used for about 40 years now, as discussed in detail by several authors. Thus, for instance, Christopher and Holtz (1985), Koerner and Robins (1986), and John (1987) have provided thorough reviews of the various geotextile applications and the corresponding design procedures. Consequently, geotextiles have found successful application as filters due to their ease to install. They are much thinner and more permeable than conventional granular filters (Giroud, 1996; Giroud, Soderman, \& Badu-Tweneboah, 1997). Also geotextiles have been successfully produced from synthetic or natural fibres depending upon their short- and long-term applications. The characteristics of natural fibres have led to their use in a range of geotextile applications namely, soil erosion control, vertical drains, road bases, river bank protection and slope stabilisation (Ahn, Cho, \& Yang, 2002; Datta, 2007; Datye \& Gor, 1994; Lekha, 2004; Mitchell et al., 2003; Rawal \& Anandjiwala, 2007; Rawal \& Saraswat, 2011a, 2011b; Saha et al., 2012; Subaida, Chandrakaran, \& Sankar, 2009; Sanyal, 2017). Other applications of such geotextiles are found in the field of chemical engineering and processing, mainly for solid/fluid 
separation. The selection of geotextile filters for achieving good performance depends on the targeted application: soil reinforcements, separators, drains in various civil and environmental engineering projects, or filters in chemical engineering and processing. In civil engineering applications, geotextiles should prevent soil suffusion which is a complex phenomenon resulting from different mechanisms including soil internal erosion (Van Thao, Marot, Rochim, Bendahmane, \& Hong Hai, 2017). Geotextiles are therefore used to play the role of filter and to prevent internal erosion of soils in contact with the filter. The purpose is mainly to allow water to pass through while keeping the soil structure stable by preventing migration. On the other hand, in the process engineering, applications are to retain the solid particles at the expense of a progressive clogging of the filter media. The performance of a geotextile filter evolves over time and depends on the variations in its properties. The clogging can be caused by physical, biological and/or chemical processes (Koerner, Lord, \& Hsuan, 1988; Rollin \& Lombard, 1988). Recently, several different clogging mechanisms influencing the long-term behaviour of geotextile filters have been investigated by Veylon, Stoltz, Mériaux, Faure, and Touze-Foltz (2016).

The present study is concerned with the understanding of a drain, designated hereafter as draining system, consisting of a layer of soil associated to a geotextile. Generally, drains can have a tubular geometry with an inner diameter of about $100 \mathrm{~mm}$; a perforated tube supports on its outside wall the geotextile membrane which is in contact with the soil. The objective of the present study is to develop a methodology allowing classifying and specifying geotextiles for this kind of applications. Literature related to this topic points out that two main fields of research have been developed in the past: the development of new tools for characterising materials using image analysis tests, and the establishment of new criteria for evaluating the performance and hydraulic compatibility of geotextiles in soil-geotextile systems. Both the shape and size distribution of the pores of nonwoven geotextiles play a key role in filtration performance. Various investigations have examined the pore size distribution of granular filters and its effect on filter selection criteria (Bhatia et al. 1998a, 1998b; Giroud, 1996; Indraratna \& Locke, 2000; Kenney et al., 1985; Locke, Indraratna, \& Adikari, 2001; Wittman 1979). Characterisation of structural parameters of geotextiles such as percent open area (PEA), pore size distribution (PSD) and constriction size by developing techniques based on image analysis have been reported by several authors (Austin, Mylnarek, \& Blond, 1997; Aydilek, Oguz, \& Edil, 2002; Mlynarek \& Lombard, 1997). For instance, Mlynarek, Lafleur, Rollin, and Lombard (1993) measured the opening filtration size of the geotextiles by the hydrodynamic sieving test which was eventually related to the general geotextile parameters such as mass per unit area and thickness. On the other hand, the compatibility of the soil/ geotextile system has generally been determined via laboratory tests such as the long-term flow test (Koerner \& Ko, 1982), the gradient ratio test (ASTM D-5101-01 2003) or the hydraulic conductivity rest (ASTM D5567-94 2011). However, these tests are time-consuming, expensive and only provide information for a specific soil/geotextile system. The filtration performance of a single-nonwoven or woven geotextile using various geomaterials has also been studied in numerous works (Akram \& Gabr, 1997; Aydilek \& Edil, 2003; Aydilek et al., 2002; Bhatia et al.1998a, 1998b; Fannin, Vaid, \& Shi, 1994; Fischer, Mare, \& Holtz,1999; Gabr \& Akram, 1996; Wayne \& Koerner, 1993). The physical and mechanical properties of hybrid needlepunched nonwoven geotextiles produced from jute and polypropylene fibres in defined proportions have been compared and analysed by Rawal and Sayeed (2013). To study the permeability behaviour of woven geotextile in the tensioned state, a series of laboratory experiments were carried out by Yiping Zhang, Liu, Shao, and Yang (2013), with woven polypropylene geotextile with tensile strength of 20-30 kN/m. A comparison of a nonwoven and a woven geotextile is presented by Portelinha, Zornberg, and Pimentel (2014) in order to evaluate of the effect of soil confinement on geotextile stiffness. The hydraulic conductivity of a geotextile is one of the key parameters for determining the duration of its use before becoming clogged. Franks, Aydilek, and Davis (2013) have developed a semi-theoretical model which predicts the hydraulic conductivity of the filter system as a function of the mass of solids captured by the geotextile.

As mentioned earlier, this work proposes a methodology in view of discriminating geotextiles for a particular application of draining systems. Considering the various approaches described above, the development of this methodology is presently based on the implementation and analysis of a large 
set of experimental steps representative of these approaches, including classical seepage flow tests as well as a structural characterisation of geotextiles, and on an empirical analysis of the experimental results. Identical experimental tests have been conducted with three commercially available nonwoven geotextiles produced from polypropylene fibres. Their efficiency for in-soil filtration and drainage of a draining system is finally discussed based on an analysis of the results.

This paper is organised as follows: in the first part, key structural parameters of geotextiles such as fibre thickness, porosity and filtration opening obtained by image analysis are presented. Water permeability normal to the plane is also reported for each geotextile. This is followed by a description of geotextile intrinsic retention capacity using a suspension of fine particles characterised by diameters smaller than the mean pore size. This means that the geotextiles are tested without supporting soil, as single filters. Quantity of the retained particles is determined and geotextile clogging is evaluated by measuring flow rate and pressure drop variation. In the third and final parts, drain systems consisting in geotextiles of contact with compacted soils are studied. Gradient Ratio (GR) is used to evaluate the behaviour of the geotextiles in two different operating conditions: a) during a long-term classical seepage flow test; b) after an instantaneous and incremental increase in flow rate (successive step signals). A detailed analysis of the data is then presented, based on the use of a dimensionless criterion proposed here as a tool to compare the performances of the geotextiles.

\section{Characteristics of geotextiles used}

Two bilayer composites, respectively, designated as '106' and '450', and one monolayer geotextile, named 'F200', from AFITEX Company (CHAMPHOL FRANCE) were used in this study. Bilayer composites are a combination of a thin layer of one geotextile and a thicker layer of a second geotextile as shown in Figure 1 for GT450. These nonwoven needle-punched geotextiles are manufactured exclusively from chemically inert polypropylene. Their physical and hydraulic properties provided by the manufacturer are presented in Table 1; they mainly describe the GT at macroscale. Other characteristic parameters have

(b)

(a)

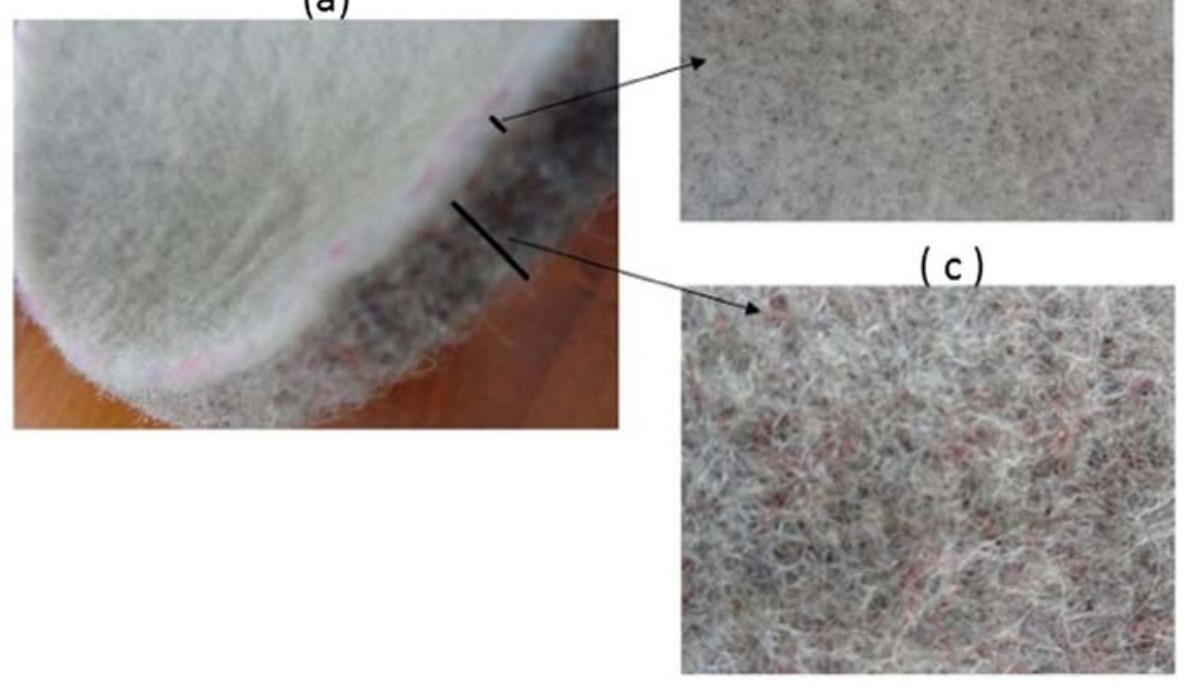

Figure 1 (a) picture of the bilayer composite (450); (b) picture of the texture of the first layer (thin layer); (c) picture of the texture of the second layer (thick layer). 
Table 1 mechanical and hydraulic characteristics of geotextiles.

\begin{tabular}{|c|c|c|c|c|c|}
\hline \multicolumn{6}{|l|}{ Mechanical characteristics } \\
\hline \multirow[b]{2}{*}{ Characteristic } & \multirow[b]{2}{*}{ Test method } & \multirow[b]{2}{*}{ Specification } & \multicolumn{3}{|c|}{ Geotextile reference } \\
\hline & & & 450 & 106 & F200 \\
\hline mass/unit area $\left(\mathrm{g} / \mathrm{m}^{2}\right)$ & nf En 9864 & total surface mass & 450 & 740 & 200 \\
\hline \multirow{2}{*}{ thickness (mm) } & nf En $9863-1$ & under 2 kpa & 5.1 & 7.1 & 2.5 \\
\hline & & under $20 \mathrm{kpa}$ & 3.9 & 5.8 & \\
\hline \multirow[t]{2}{*}{ tensile strength $(\mathrm{kn} / \mathrm{m})$} & nf En iSo 10319 & longitudinal direction & 12 & 20 & 6 \\
\hline & & transverse direction & 12 & 20 & 6 \\
\hline \multirow[t]{2}{*}{ Elongation-at- break (\%) } & nf En iSo 10319 & longitudinal direction & 110 & 110 & 90 \\
\hline & & transverse direction & 110 & 110 & 90 \\
\hline $\begin{array}{l}\text { pyramid puncture resistance } \\
\text { (kn) }\end{array}$ & nf g 38-019 & & 1.5 & 2.9 & 0.6 \\
\hline $\begin{array}{l}\text { dynamic perforation test (cone } \\
\text { drop test) (mm) }\end{array}$ & nf En iSo 13433 & & 10 & 4 & 25 \\
\hline $\mathrm{CBr}$ puncture resistance $(\mathrm{kn})$ & nf En iSo 12236 & & 2.7 & 4.5 & 1.2 \\
\hline \multicolumn{6}{|l|}{ Hydraulic characteristics } \\
\hline \multirow[t]{2}{*}{ Characteristic } & test method & Specification & \multicolumn{2}{|c|}{ geotextile reference } & \\
\hline & & & 450 & 106 & $\mathrm{f} 200$ \\
\hline filtration opening size of $(\mu \mathrm{m})$ & nf En iSo 12956 & filter fabric & 80 & 80 & 80 \\
\hline $\begin{array}{l}\text { Water permeability normal to } \\
\text { the plane }\left(1 / \mathrm{s} / \mathrm{m}^{2}\right)\end{array}$ & nf En iSo 11058 & filter fabric & 100 & 110 & 100 \\
\hline \multirow[t]{4}{*}{ plane flow capacity $\left(\mathrm{m}^{2} / \mathrm{s}\right)$} & nf En iSo 12958 & gradient $i=1$ & & & \\
\hline & & under 20 kpa & & $4.3 \times 10^{-5}$ & \\
\hline & & under 50 kpa & & $3.5 \times 10^{-5}$ & \\
\hline & & under $100 \mathrm{kpa}$ & & $1.1 \times 10^{-5}$ & \\
\hline
\end{tabular}

then been determined in this work so as to develop some understanding at a microscale, as shown in Table 2. The mean diameter of fibrep, id measured using optical microscopy and image analysis. Typical results on fibre sizes are shown in the optical micrograph in Figure 2. Porosity, $\mathrm{n}$, is calculated from:

$$
\mathrm{n}=1-\frac{\mu_{\mathrm{g}}}{\rho_{\mathrm{g}} \mathrm{T}_{\mathrm{g}}}
$$

Where $\rho_{g}\left(\mathrm{~kg} / \mathrm{m}^{3}\right)$ is the density of the geotextile ${ }_{g} \mu\left(\mathrm{kg} / \mathrm{m}^{2}\right)$ is mass per unit area of geotextile, and $T_{g}(\mathrm{~m})$ is the thickness of the geotextile $e_{\dot{g}}$ is determined by cutting a minimum of 10 square samples from a roll, each sample measuring at least $100 \mathrm{~mm}$ long, and then weighing them using an accurate scale. Filtration opening size, , Ois usually given by the near-largest constriction size of a particular geotextile. Giroud (1996) performed a mathematical analysis and developed a relationship between $O_{f}$ and nonwoven geotextile thickness, $: T$

$$
\frac{\mathrm{O}_{\mathrm{f}}}{\mathrm{d}_{\mathrm{f}}}=\frac{1}{\frac{1}{1-\mathrm{n}}}-1+\frac{\xi \mathrm{n} \mathrm{d}_{\mathrm{f}}}{(1-\mathrm{n}) \mathrm{T}_{\mathrm{g}}}
$$

\begin{tabular}{|c|c|c|c|c|}
\hline \multirow[b]{2}{*}{ Parameter } & \multirow[b]{2}{*}{ Type of layer } & \multicolumn{2}{|c|}{ Bilayer composite geotextile } & \multirow{2}{*}{$\frac{\text { Monolayer geotextile }}{\text { F200 }}$} \\
\hline & & 106 & 450 & \\
\hline \multirow[t]{2}{*}{$\overline{d_{f}(\mu m)}$} & thin & 28.6 & 26 & 28.8 \\
\hline & thick & 69.2 & 50.6 & \\
\hline \multirow[t]{2}{*}{$n$} & thin & 0.86 & 0.85 & 0.90 \\
\hline & thick & 0.88 & 0.89 & \\
\hline \multirow[t]{2}{*}{$O_{f}(\mu m)$} & thin & 55 & 52 & 89 \\
\hline & thick & 183 & 140 & \\
\hline \multirow[t]{2}{*}{ Constriction number, $m$} & thin & 77 & 58 & 28 \\
\hline & thick & 35 & 34 & \\
\hline
\end{tabular}

Table 2. Characteristics of geotextiles determined from image analysis and using literature models. 


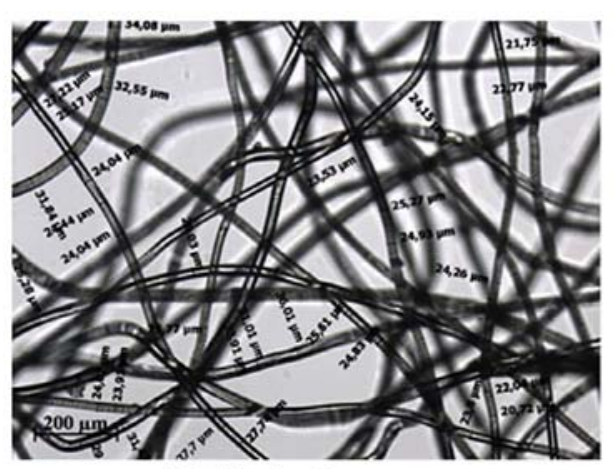

106 (thin layer)

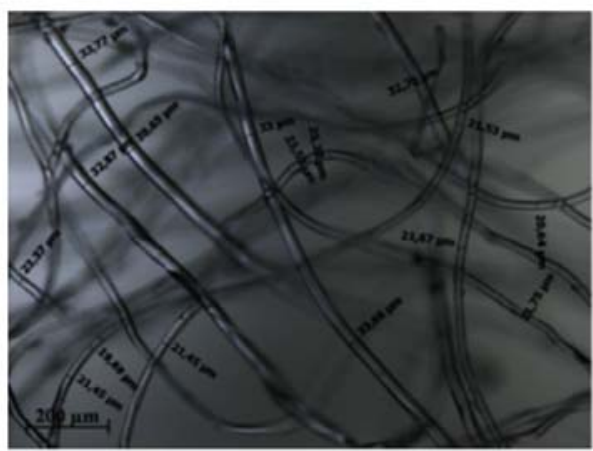

405 (thin layer)

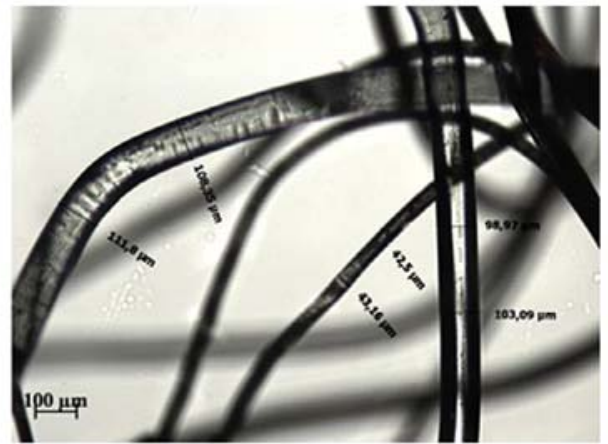

106 (thicker layer)

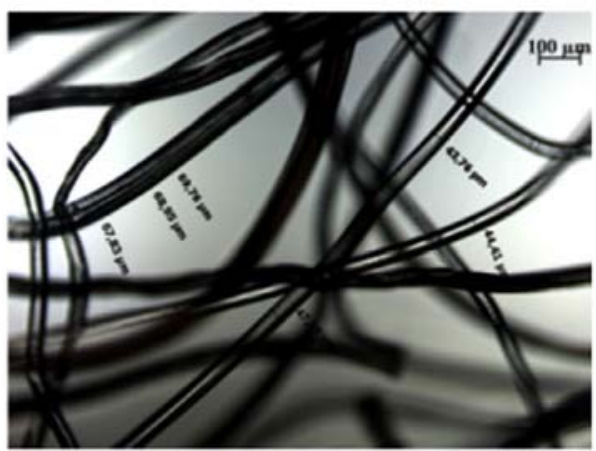

405 (thicker layer)

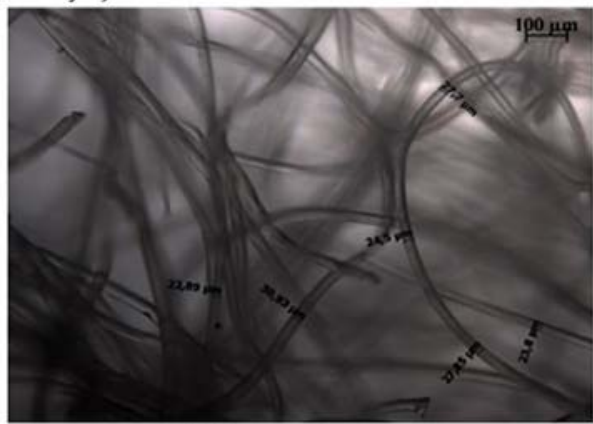

F200 (monolayer)

Figure 2 optical micrographs of polypropylene nonwoven fibres of the three geotextiles.

The constant $\xi=10$ was obtained by Rigo, Mathieu, Smolders, and Alexandre (1990) through a calibration based on a large number of experimental data gathered from 52 laboratories. Based on the material properties of the geotextile ${ }_{f}$, Opening is estimated here using relationship given by Equation (2). Constrictions are defined as the narrowest sections of channels between larger cavities within the pore network of porous media and are the main obstacles for a small particle to overcome when flowing along such pathways. Giroud (1996) demonstrated that the geotextile must possess an optimum number of constrictions, designated as $\mathrm{m}$, to ensure that the filter is neither too permeable for the soil nor too prone to clogging:

$$
m=\frac{T_{g}}{d_{f}} \sqrt{(1-n)}
$$


Based on the properties of the geotextiles used, constriction numbers are estimated here from relationship 2 (Table 2).

Darcy's law is given by:

$$
\frac{\Delta \mathrm{P}}{\mathrm{L}}=\frac{\mu}{\mathrm{B}} \frac{\mathrm{Q}^{)}}{\mathrm{A}}
$$

Where $B\left(\mathrm{~m}^{2}\right)$ is the absolute permeability, $L(\mathrm{~m})$ is the length of flow (material thickness) across which the head is dissipated, $Q\left(\mathrm{~m}^{3} / \mathrm{s}\right)$ is the flow rate (hydraulic discharge rate), $\Delta P(\mathrm{~Pa})$ is the pressure drop through the porous media, $A\left(\mathrm{~m}^{2}\right)$ is the cross-section area available to flow and $\mu(\mathrm{Pa} \mathrm{s})$ is the viscosity of the fluid.

Hydraulic conductivity, $K$, is a basic physical property which is used to evaluate the performance of a filter medium like a drainage system. Hydraulic conductivity is generally reported in $\mathrm{cm} / \mathrm{s}$ or m/s, and expressed according to the Darcy's law:

$$
\frac{\mathrm{Q}}{\mathrm{A}}=\mathrm{K} \frac{\Delta \mathrm{H}}{\mathrm{L}}=\mathrm{Ki}=\mathrm{u}_{0}
$$

The hydraulic gradient, $i(\mathrm{~m} / \mathrm{m})$, represents the head loss per unit length of medium. Head loss, $\Delta H(\mathrm{~m})$, is related to the pressure drop $\triangle P(\mathrm{~Pa})$ according to the following relationship:

$$
\Delta \mathrm{P}=\rho \Delta \mathrm{H}
$$

Where $\rho$ is the fluid density $\left(\mathrm{kg} / \mathrm{m}^{3}\right)$, and $\mathrm{g}$ is the acceleration due to gravity. The hydraulic conductivity $K$ of a soil is also related to the properties of the fluid flowing through it by the equation:

$$
\mathrm{K}=\frac{\rho \mathrm{g}}{\mu} \mathrm{B}
$$

In practice, reliable determination of the permeability of the geotextile according to Darcy's law (Equation 5) is rather difficult due to the lack of accuracy in the measurement hydraulic gradient. Hence, the water permeability commonly obtained during the tests with the geotextiles is defined in terms of flow rate per unit area for a known driving pressure. In this study, tests were performed following this reference method. The geotextile is subjected to a unidirectional flow of water normal to the plane, while the pressure on the geotextile is held constant throughout the test. The quantity of water that passes through the sample is measured as a function of time for four different fixed pressures $(10,20$, 30 and $40 \mathrm{kPa}$ ). Figure 3 shows schematically the device used in the work. A total of three tests are performed with each type of geotextile in order to check reproducibility; the average values obtained are reported in Table 3. Attention is drawn to the fact that the value of permeability provided by the manufacturer (Table 2) differ from the ones obtained from our tests. Indeed, the measurements carried out by the manufacturer were performed following the standard method NF EN ISO 11058. According to our results (Table 3 ), the monolayer geotextile (F200) provides a relatively great flow rate per unit

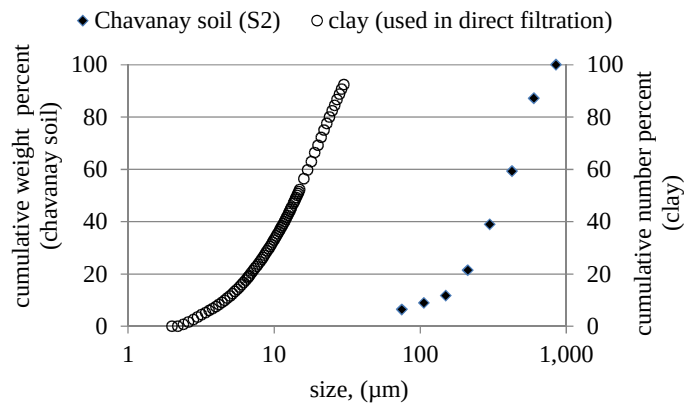

Figure 3. Size distributions of clay particles in suspension and Chavanay soil $\left(S_{2}\right)$. 
Table 3. average values for flow rate per unit area.

\begin{tabular}{lccc}
\hline Pressure $(\mathrm{kPa})$ & Flow velocity $\times 10^{3}$ (volume per unit of time and area: $\left.\mathrm{m}^{3} / \mathrm{m}^{2} \mathrm{~s}\right)$ \\
\hline Geotextile & F200 & 450 & 106 \\
\hline 10 & 14.2 & 13.7 & 13.2 \\
20 & 19.5 & 18.4 & 17.9 \\
30 & 23.6 & 22.5 & 21.9 \\
40 & 26.8 & 25.8 & 24.9 \\
\hline
\end{tabular}

area and is more permeable under the operational conditions for that use. The two bilayer composites GT exhibit similar behaviours.

\section{Filtration and seepage tests}

The laboratory trials undertaken to evaluate the filtration performance of the nonwoven geotextiles are classified into two configurations (see the corresponding set-ups in Figures 4 and 5):

(i) First, a direct filtration of a dilute suspension is carried out through the GT only. This allows us to evaluate the geotextile's intrinsic retention capacity on the fine particles that arrive at the soil-GT interface. In practice, the particles of the soil entrained by a stream of water can either be blocked upstream of the filter or enter into the filter structure where they either get trapped or pass through the filter. The test is therefore performed with dilute clay slurry in order to consider the case where fine particles could migrate through the layer of soil and thus reach the GT membrane. Obviously, the geotextile being in contact with soil would behave differently, but it might be emphasised here that its behaviour would depend on many factors such as the soil nature, the history of filtration, and so on. Therefore, this test is supposed to establish a reference for the evaluation of the GT concerning its retention capacity towards fine particles. This part of the work is developed in Section 3.1.

(ii) The GT are then tested and compared as a part of draining systems, each of them consisting of a GT sheet covered by a layer of draining soil. For this purpose, filtration is performed through the geotextile deposited in contact with a $20-\mathrm{cm}$-deep layer of soil. The comparison is made possible as the same kind of soil is used for the three GT. Each of these tests consists of monitoring change in flow rate through the porous material during a long-term flow time (over $200 \mathrm{~h}$ ). Gradient ratio (GR) and hydraulic conductivity ratio (HCR) are obtained from the of differential pressure data across a section of the soil and across the interfacial layer comprising the geotextile and the soil contact zone. After about $150 \mathrm{~h}$ of filtration, a final test is carried out to analyse the sensitivity of the system to variations caused by instantaneous changes of flow rate, simulating flow

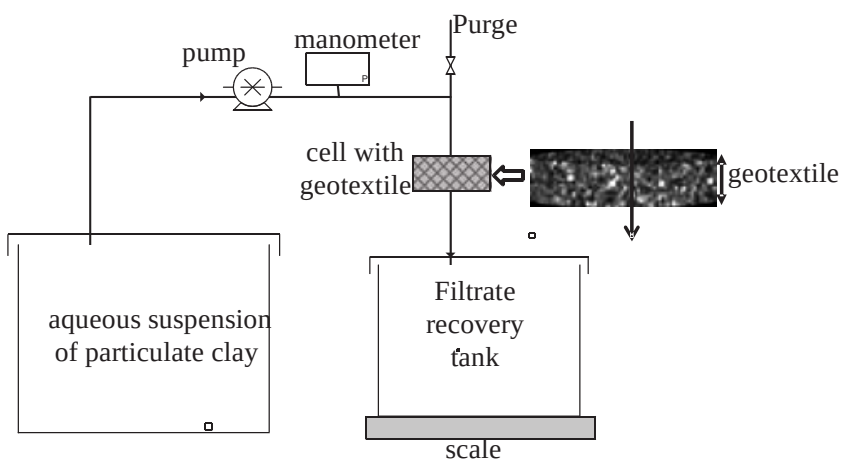

Figure 4. Schematic illustration of direct filtration through the geotextile. 


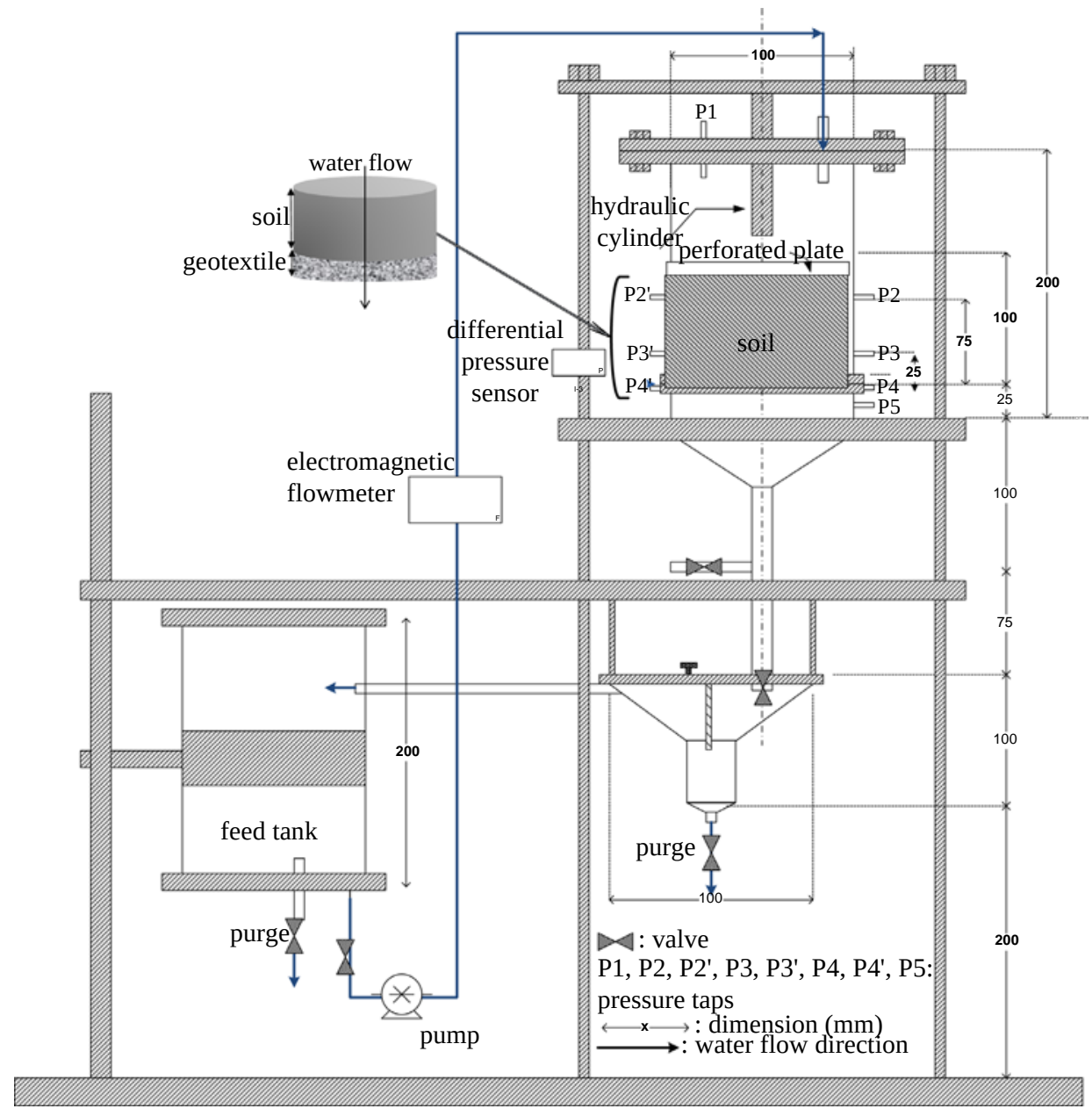

Figure 5. Schematic illustration of direct filtration through the geotextile.

perturbations that may occurs during seeping flow. This test consists of recording the pressure gradient and actual measured flow rate following a sudden change of the imposed flow rate.

Sections 3.1.1 and 3.2.1 present the specific experimental protocols developed as well as their results and analysis.

\subsection{Direct filtration of a suspension through the geotextile}

\subsubsection{Materials and method}

A suspension of $1 \mathrm{~g} / \mathrm{L}$ clay was prepared and then filtered for at least 50 min under a constant pressure of 0.1 bar. The size distribution of the clay particles in suspension is measured using a laser diffraction size analyzer (QICPIC, Sympatec, Clausthal-Zellerfeld, Germany) capable of analysing particle sizes in the range 1-2000 $\mu \mathrm{m}$. It consists of a LIXELL wet dispersion system through which sample passes. Bowl position is controlled by Windox particle-sizing software. Cumulative number percent and density distribution are plotted in Figure 3. The tests were carried out using an experimental filtration device (Figure 4). Average measured turbidity is about 986 NTU ( \pm 100 NTU). Samples of each GT (47 mm in diameter) were prepared for the purpose of these tests. The cut samples are placed in a cylindrical cell, 
perpendicular to the main direction of flow (frontal filtration). In the tests, bilayer geotextiles GT 106 and GT 450 were placed in such a way that the incoming flow passes through the finest layer. Cumulative mass of clay suspension was continuously measured by a scale connected to a computer. During the course of the test, the mass of filtrate collected is monitored over time to assess changes in the flow over time. Samples were weighed before and after filtration in order to deduce the amount of solid particles that get trapped by the filter.

\subsubsection{Results and discussion}

The present results show very little retention within all three types of geotextile; percent retention obtained with F200, 106 and 450, based on the total mass of clay to the filter inlet during the filtration period, were estimated to be as $0.9,1.8$ and $2.7 \%$, respectively. However, despite such a low level of retention, the results are very different in terms of filtration behaviour in this configuration. Both filters 106 and 450 showed a significant drop in filtrate flow rate (Figure 6) after ten minutes, whereas filtrate flow rate through the monolayer filter (F200) was almost constant.

The higher sensitivity to clogging observed with the bilayer filters can be attributed to their particular structure containing a thin layer which has relatively narrow openings. The thin layers of the two bilayer composites have practically identical fibre diameters and porosities. The constrictions correspond to the free cross-section from one pore to another through the filter. Increasing the number of constrictions per unit of thickness consequently decreases the probability of passage of a given particle. The particles retained in the pores may occupy positions that significantly reduce the permeability of the porous media; this induces more pressure loss and an increased tendency for clogging. In the thickness of thin layers of the bilayer composites (450 and 106), there are at least two times more constrictions than in the monolayer geotextile (F200), and thus bilayer GT clog faster (Figure 6).

This kind of tests allows to characterise the intrinsic properties of the GT and to discriminate their behaviour in such situation. However, this is obviously not sufficient to predict their behaviour in draining systems or too give firm conclusions on how effectively these materials will perform as filters when they are actually in contact with soil. Indeed, the clay particles pass through geotextile F200, which seem to clog less, but that is not enough to predict its effectiveness at stopping the soil from sliding and thus maintaining its cohesion.

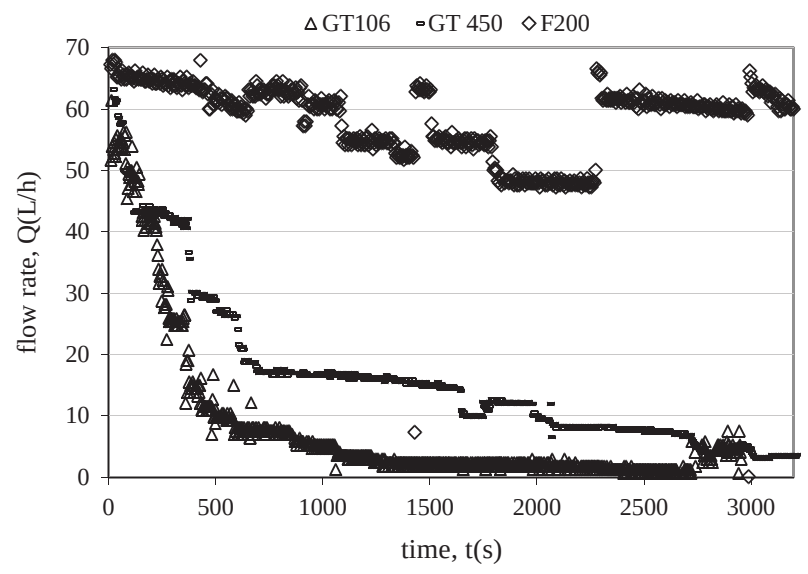

Figure 6. time-course of flow rate during filtration through the geotextile without being in contact with soil. 


\subsection{Evaluation of geotextiles performances in a draining system}

\subsubsection{Materials and methods}

A second experimental device (Figure 5) developed specifically for this study was designed to simulate the behaviour of a draining system. Each of the tested draining systems consists of one of the three tested GT covered by a layer of an identical soil. In this kind of application, the objective is to allow easy passage of seepage water through the layer of soil while retaining soil particle retention to prevent erosion and lend stability of geotechnical structures or soils. The device (Figure 6) comprises different elements; water is contained in a 5-litre tank and flows through the system by means of a magnetic drive gear pump. A $100 \mathrm{~mm}$ internal diameter Plexiglas cell with 10-mm-thick walls contains the soil sample, up to a $20 \mathrm{~cm}$ height. A pneumatic cylinder that applies a soil confining pressure of 0 to 5 bar is placed at the entry to the cell. Flow rate is measured upstream of the cell using an electromagnetic flowmeter (PROMAG - Endress \& Hauser) over a range from 2 to $113 \mathrm{~L} / \mathrm{h}$ accurate to $0.5 \%$. Two differential pressure sensors (Deltabar - Endress \& Hauser) are used for measurements, in a range from 0 to $300 \mathrm{mbar}$.

\subsubsection{Two model soils were selected for this study. The first model soil (\$ is an artificial material} composed of $92 \%$ sand and $4 \%$ silt. Commercial sand was sifted, and only classes between 0.212 and $0.300 \mathrm{~mm}$ were selected to be mixed with silt to prepare the samples used during the tests. This soil can be considered as monodispersed.

The second model soil $)_{2}$ (\$s a natural soil recovered near a dam located in Chavanay, France. Gradation and grain-size distribution are shown in Figure 4. This sand can be considered as a wellgraded soil as the value of its coefficient of uniformity, $\mathrm{Cu}$, is four, and its coefficient of gradation or curvature, $\underset{C}{C}$, is equal to 1.5. The definitions of these parameters are given in Equations (8) and (9).

$$
\begin{gathered}
C u=\frac{d_{10}}{d_{60}} \\
C_{c}=\frac{\left(d_{30}\right)_{2}}{d_{10} d_{60}}
\end{gathered}
$$

Where $d_{60}$ is the grain diameter at $60 \%$ passing, thle grain diameter at $30 \%$ passing and the grain diameter at $10 \%$ passing.

The geotextile membrane is deposited on a perforated stainless steel plate. The geotextile sample covers a wider circular space than the rest of cell, meaning the circumferential edge of the sample is positioned beyond the inner wall of the cell, which minimises parietal channelling.

An o-ring whose thickness is a function of geotextile thickness is fitted to fill the remaining space in this box before positioning the measuring cell on the carrier. The cell is first filled with water, then the soil is carefully mixed and introduced in successive small amounts to prevent bubbles getting into the system and reach near-saturation conditions. The system preparation protocol prior to each test is identical in order to have comparable conditions for evaluating filter behaviour. Once the geotextile and soil are placed in the cell, the pump is switched on to circulate water through the system in downward direction. The pressure sensors are then connected and a purge is performed at each of the four pressure taps to evacuate any bubbles that could otherwise influence the measurements. Once all trapped air has been removed, data acquisition can be started. The differential pressure is measured upstream and downstream of two selected sections:

- The first section consists of soil only. The calculations of hydraulic gradient are obtained using pressure drop data from pressure sensors located 25 and $75 \mathrm{~mm}$ from the geotextile layer. The measurements of hydraulic gradient $i$ are performed on a thickness of $f 50 \mathrm{~mm}$, between the 
pressure taps (Por $\left.P_{2}^{\prime}\right)$ and $\left(P_{3}\right.$ or $\left.P_{3}^{\prime}\right)$ (Figure 6). The subscript 'soil' used in the equations below refers to this section.

- The second section includes the geotextile and the interfacial thin soil layer (soil/geotextile). The subscript 'GT + interface' refers to the pressure drop measurement for this section. The thickness across which head loss is measured in this zone is designate ( $_{\mathrm{B}} \mathrm{py}_{\text {interface) }}=25 \mathrm{~mm}$. The measurements are performed in this area between the pressure tapsof $\left(P_{3}^{\prime}\right)$ and $\left(P_{4}\right.$ or $\left.P_{4}^{\prime}\right)$.

The hydraulic gradient i of the filter zone and the soil are obtained from pressure drop measurements in these areas via the following formulas:

$$
\mathrm{i}_{\text {soil }}=\frac{\Delta \mathrm{H}_{\text {soil }}}{\mathrm{L}_{\text {soil }}} ; \mathrm{i}_{\text {(GT+interface })}=\frac{\Delta \mathrm{H}_{(\mathrm{GT}+\text { interface })}}{\mathrm{L}_{\text {(GT+interface })}} ;
$$

Gradient ratio, GR, of the filtration systems is defined as the ratio of hydraulic gradient through the geotextile-soil interface zone to hydraulic gradient through the soil alone:

$$
G R=\frac{i_{(G T+\text { interface })}}{i_{\text {soil }}}
$$

Hydraulic conductivity ratio (HCR) is defined as the hydraulic conductivity of the soil /divided by the equilibrium hydraulic conductivity of the contact zone comprising the geotextile and interface zone $K_{(G T+\text { interface) }}$

$$
\mathrm{HCR}=\frac{\mathrm{K}_{\text {soil }}}{\left.\mathrm{K}_{\mathrm{GT}+\text { interface }}\right)}
$$

A data acquisition system records continuously the delivered flow rate and corresponding pressure drop over a period of one week. Control checks are done at regular intervals during the test to check for any potential disturbances, whether related to data processing or to the hydraulic system, such as the presence of air pockets or other anomalies (pump, sensors and piping). After one week of flow at fixed flow rate, a series of instantaneous flow variations is carried out. The objective of these complementary tests is to check the behaviour of the material following an instantaneous increase in flow. These tests consist of causing a step signal variation of flow rate from an initial value termetc a greater value termed $Q$ and recording the corresponding time-course of the measured pressure drop over a 5-min period, after which flow rate is reverted back to its initial value. As illustrated in Figure 7, this operation is reproduced over $3 \mathrm{~h}$ with 30 -min periods. These periodic tests were also carried out

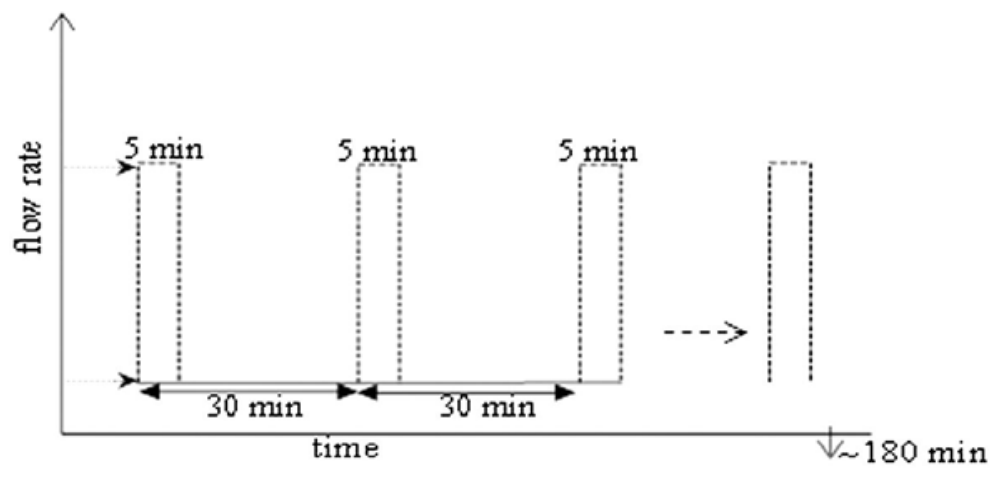

Figure 7. Schematic diagram of the instantaneous flow variation test protocol. 
by increasing the flow rate from the initial value to a greater valuę $\bigotimes_{2}$ over the same duration (3 h) with the same periods (30 $\mathrm{min})$.

\subsubsection{Results and discussion}

3.2.2.1. Long-term tests. Table 4 summarises the results obtained in the long-term tests on the various systems, once flow rate and hydraulic gradient had become constant. The values presented were obtained by averaging the recorded values without taking into account the data acquired in the initial period where flow rate and pressure gradient were not yet stable. The results indicate that the soil $S_{1}$ is much more permeable than ${ }_{2} S_{1}$ is characterised by a rather monodisperse size dispersion whereas Sexhibits a relatively large size dispersion of particles. For a given geotextile, on the other hand, the value of the hydraulic gradient through the geotextile and its interfaçe ${ }_{+} i_{\text {interface })}$ as well as their corresponding permeability are relatively insensitive to the soil used. Moreover, the permeability of soil $S_{1}$ is of the same order of magnitude than that in the geotextiles and their interface, thus complementary tests performed with instantaneous flow variations were carried out only with s.oThe permeability of soil Ş is lower than that of the geotextiles and their interface, which is a more realistic situation.

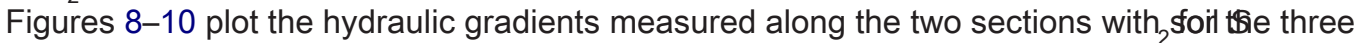
geotextiles, respectively. These plots highlight a fluctuation phase where throughput was variable and flow behaviour was unstable. This initial period lasted $40-48 \mathrm{~h}$ from the start of water circulation. During this phase, flow rate and pressure drop increased, with fluctuations, through the system. After this period, flow rate and hydraulic gradient remained steady. These fluctuations can be attributed to water flow in unsaturated conditions, i.e. in which the soil pores are not all filled with water. Due to the pressure loss, the actual flow rate value reached in steady flow regime is lower than the set point flow rate value of the pump (engine speed) which had been set at a fixed $30 \mathrm{~L} / \mathrm{h}$ for all the geotextiles. The lowest stabilised flow rate was obtained with geotextile F200. The flow rate per unit area was higher when this geotextile was used without being in contact with soil. For the two other geotextiles, the real flow was about $11.7 \mathrm{~L} / \mathrm{h}$ for 106 and $18.8 \mathrm{~L} / \mathrm{h}$ for 450.

When using GT F200 in the draining system, a significant increase $(+70 \%)$ in the hydraulic gradient within the soil section (from 17 to $57 \mathrm{~m} / \mathrm{m}$ ) was observed during a period of $120 \mathrm{~h}$ (Figure 10). This significant and continuous increase stops at $120 \mathrm{~h}$; a sudden decrease is then observed, followed by a slower one. During this period (120-140 h), the hydraulic gradient at the GT and the soil interface increases by a factor 25 showing that at about $t=120 \mathrm{~h}$ the draining system may has suffered from a sudden migration of particles from the soil section to the GT + interface section. As can be seen in Figure 10, this sudden change in overall structure of the medium is following a long period (120 h) of successive migration and interception of fine particles that leads to a progressive reduction of the permeability of the soil. The average circulation flow rate through geotextile F200 during the test was approximately $8.6 \mathrm{~L} / \mathrm{h}$.

Table 4. Summary of the values obtained for gradient ratio and hydraulic conductivity in the soil and geotextile under long-term flow tests at constant flow rate $Q_{1}$.

\begin{tabular}{|c|c|c|c|c|c|c|c|}
\hline \multirow{2}{*}{$\begin{array}{l}\text { Geotextile } \\
\text { Soil }\end{array}$} & \multirow[b]{2}{*}{ Unit } & \multicolumn{2}{|c|}{106} & \multicolumn{2}{|c|}{450} & \multicolumn{2}{|c|}{$\mathrm{F} 200$} \\
\hline & & 1 & 2 & 1 & 2 & 1 & 2 \\
\hline $\begin{array}{l}\text { actual flow rate } \\
Q_{1}\end{array}$ & $\mathrm{l} / \mathrm{h}$ & 20.5 & 11.7 & 30 & 18.8 & 23.8 & 8.6 \\
\hline$i_{\text {soil }}$ & {$[-]$} & 1.7 & 12.2 & 2.3 & 8.16 & 1.38 & 33 \\
\hline$i_{(g t+\text { interface })}$ & & - & 1.41 & 1.5 & 1.75 & 1.11 & 0.8 \\
\hline $\operatorname{grt}=i$ (gt + interface) $/ i_{\text {soil }}$ & & - & 0.12 & 0.65 & 0.21 & 0.8 & 0.02 \\
\hline $10^{5} \times \mathfrak{K}_{\text {soil }}^{\text {gintertace }}$ & $\mathrm{m} / \mathrm{s}$ & 4.26E-04 & 5.97 & 31.6 & 8.88 & 52.5 & 2.20 \\
\hline $10^{5} \times K_{(g t+\text { interface })}$ & & - & 51.3 & 48.3 & 41.3 & 65.3 & 90.4 \\
\hline $10^{5} \times K_{\text {syst }}^{(\text {(gi i miterlace) }}$ & & - & 8.46 & 35.7 & 12.0 & 56.2 & 3.26 \\
\hline$K_{r}=K_{\text {soil }}^{\text {syst }} / K_{\text {system }}$ & {$[-]$} & & 0.71 & 0.88 & 0.74 & 0.93 & 0.67 \\
\hline$K_{\text {(gt + interface) }} / K_{\text {system }}^{\text {solite }}$ & & & 6.06 & 1.35 & 3.43 & 1.16 & 27.73 \\
\hline$K_{\text {soil }} / K_{\text {(gt }+ \text { interface })}$ & & & 0.116 & 0.654 & 0.215 & 0.8 & 0.024 \\
\hline $10^{12} \times B_{\text {soil }}$ & $m^{2}$ & 43.6 & 6.09 & 32.2 & 9.07 & 53.7 & 2.25 \\
\hline $10^{12} \times B_{(\mathrm{gt}+\text { interface })}^{\text {siin }}$ & & - & 52.4 & 49.4 & 42.2 & 66.7 & 92.3 \\
\hline
\end{tabular}




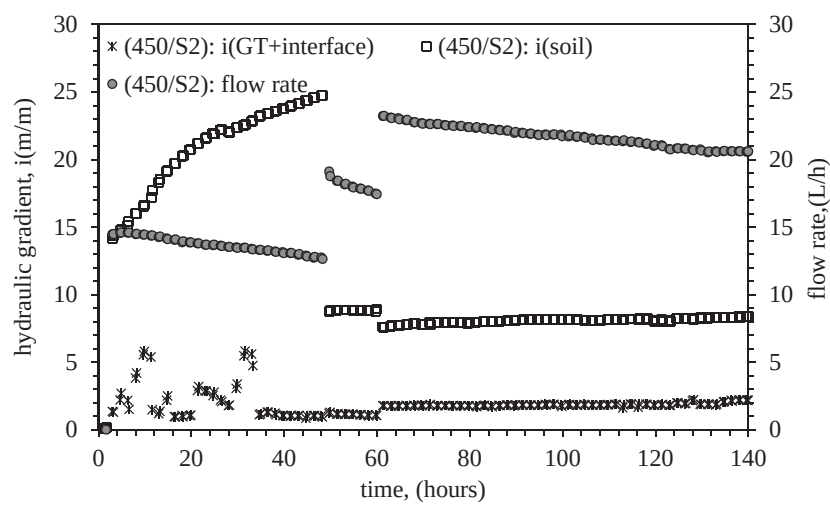

Figure 8. Hydraulic gradient responses for soil $S_{2}$ with geotextile 450 during long-term flow time.

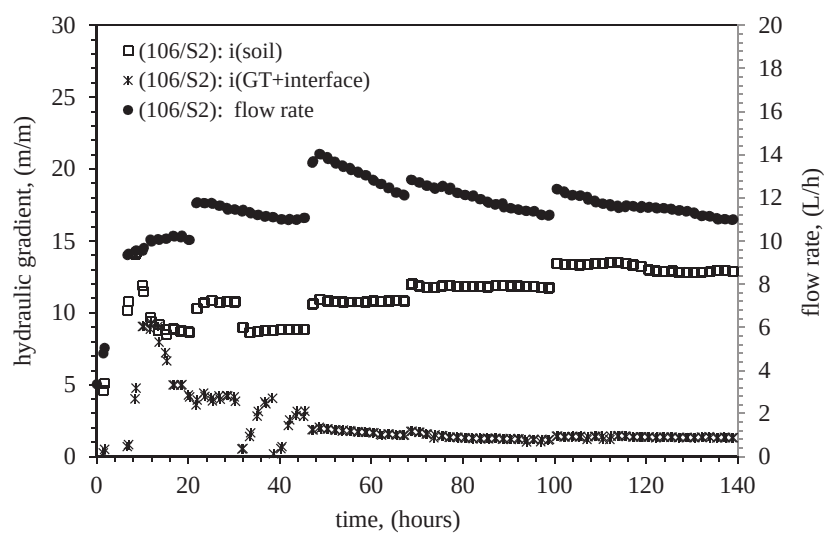

Figure 9. Hydraulic gradient responses for soil $S_{2}$ with geotextile 106 during long-term flow time.

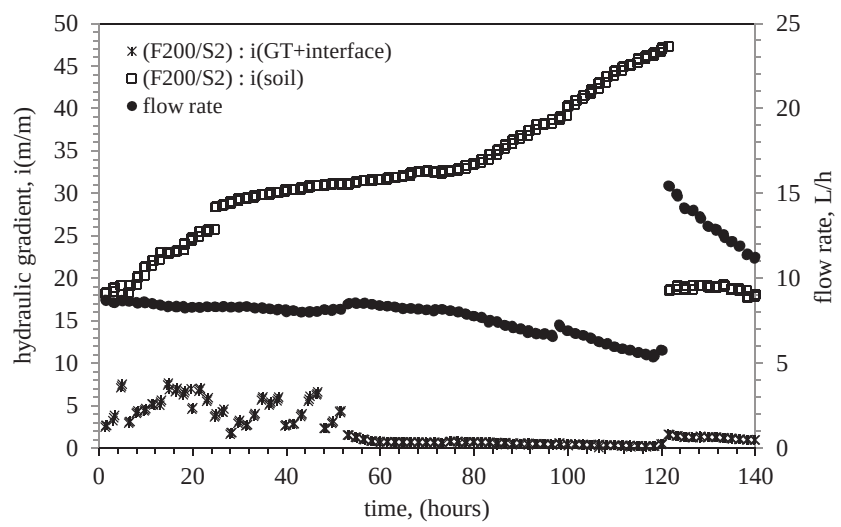

Figure 10. Hydraulic gradient responses for soil $S_{2}$ with geotextile f200 during long-term flow time.

Furthermore, the hydraulic gradient in the soil section varied by $+26 \%$ (between 10.6 and $13.6 \mathrm{~m} / \mathrm{m}$ ) with geotextile 106, for an actual flow rate of $14 \mathrm{~L} / \mathrm{h}$. Geotextile 450 allowed a higher actual water flow rate and a lower in-soil hydraulic gradient compared to the two other geotextiles. The peak hydraulic 
gradient obtained with geotextile 450 in the soil section was about 33\% lower than that for GT 106 in the draining system and 84\% lower than that observed with the draining system using GT F200.

Gradient ratio GR and hydraulic conductivity ratio HCR, as defined earlier, were used to analyse the results of the long-term tests. As already mentioned, the permeability values (Table 4) suggest that the structure formed in the soil-geotextile interface area is more permeable than the basic soil itself. Table 4 shows that GR values obtained using soilrænged from 0.02 (for F200) to 0.21 (for 450), indicating that the hydraulic gradient in the 'geotextile-thin soil layer interface' was far lower than the hydraulic gradient of the soil section. Figure 11 plots the GR values for swilt $\$$ geotextile 450 during long-term flow time. Concerning soil \$ GR values were comparable for geotextiles 450 and F200, with a value relatively close to one, whereas for soiltiße GR values for all geotextiles were much lower than one. Based on the results available in the literature concerning GR limit values (Fannin et al., 1994; Lafleur, Francoeur, \& Faure, 2002), a GR less than 1 may imply the movement of fine-grain soil through the geotextile openings. The [\$200] draining system had a significantly lower GR value, indicating that the zone comprising geotextile F200 and the thin soil layer in interface is much more permeable than the soil layer. However, as these are relative values, it is reasonable to assume that only geotextile F200 may present a risk of leaching when used with soil. Given that the thickness of the soil-geotextile contact zone is relatively small, a different criterion was used to check the accuracy of the GR values, as suggested in previous studies, (Aydilek et al., 2002; Fischer, 1994). The hydraulic conductivity of the draining system ( $K_{\text {Stem }}$ ) is determined using the hydraulic gradient applied on the soil-geotextile system. $K_{\text {system }}$ is obtained from the measurements performed between the pressure tapsr $\mathbb{P}_{2}^{\prime}$ and $P_{4}$ or $P_{4}^{\prime}$ on a thickness of $7.5 \mathrm{~mm}$. The permeability ratiß, defined as the ratio of soil hydraulic conductivity $\left(K_{\text {soi }}\right)$ to system hydraulic conductivity $\left(K_{\text {S }}\right.$ stem $)$, is used as an alternative criterion. Clogging of the geotextile should result in a decrease in system permeability giving a soil permeability-to-system permeability ratio, $k$, greater than unity. Concerning the three studied systems, this ratio remains below than 1 (Table 4). Thus, it can be considered that the geotextiles used here are not clogged.

3.2.2. Instantaneous flow variation tests. During the instantaneous flow variation tests, flow rate was suddenly increased from the set point value $\beta 0 \mathrm{~L} / \mathrm{h}$ to a new set point $\Theta 60 \mathrm{~L} / \mathrm{h}$ or $\Omega_{3}=80 \mathrm{~L} / \mathrm{h}$. Figures 12-16 plot the time-course of hydraulic gradient after applying several sudden changes in flow rate. These tests were carried out using soilnSexperiments, the actual flow rate values obtained are lower than the target sets. The flow rate values displayed by the flowmeter (Table 5) were closer to the set values when testing GT450, and the scatter between the set value and the real value reached experimentally after variation were $35.7 \%$ for $60 \mathrm{~L} / \mathrm{h}$ and $33 \%$ for $80 \mathrm{~L} / \mathrm{h}$, respectively. For the other geotextiles, even greater variations were observed between the set values and real ones, the scatter between set value and real value for F200 reaching $67 \%$ for $60 \mathrm{~L} / \mathrm{h}$ and $72 \%$ for $80 \mathrm{~L} / \mathrm{h}$. Given that the

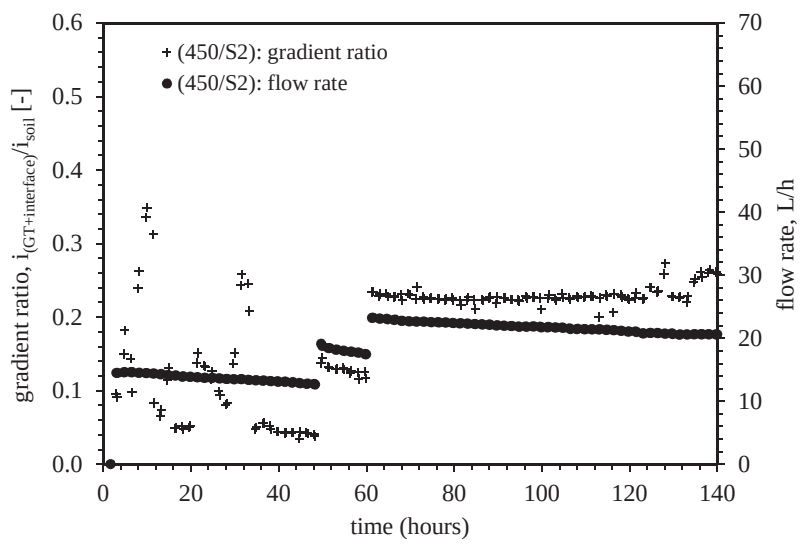

Figure 11. gradient ratio values obtained for soil $S_{2}$ with geotextile 450 during long-term flow time. 


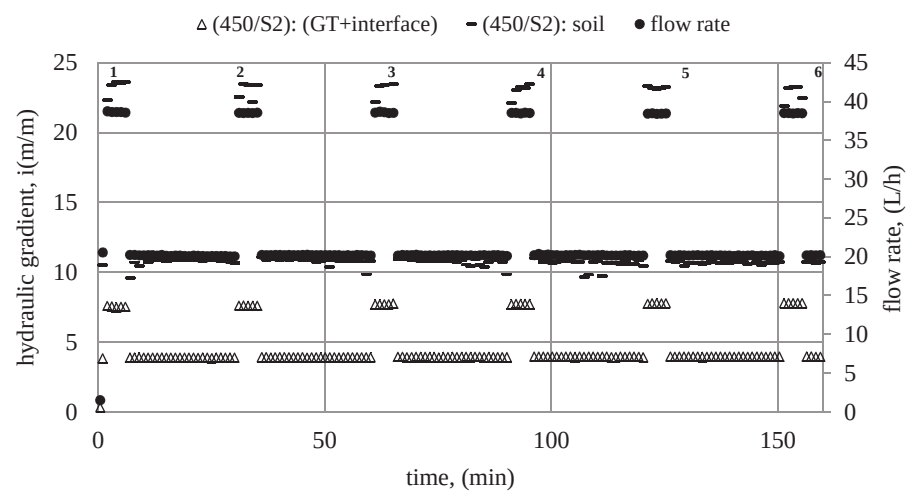

Figure 12. Hydraulic gradient responses to the imposed instantaneous changes $\left(Q_{1}-Q_{2}\right)$ of flow rate with the system $\left(450 / S_{2}\right)$.

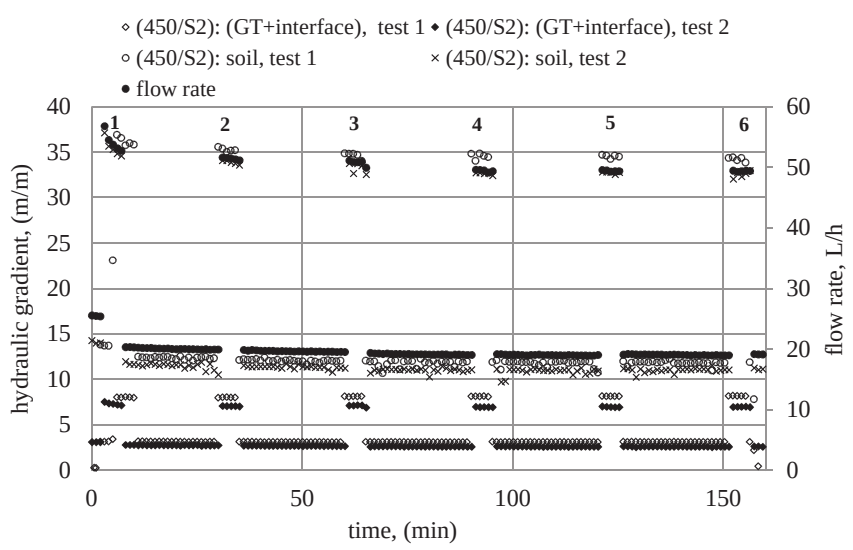

Figure 13. Hydraulic gradient responses to the imposed instantaneous changes $\left(\begin{array}{ll}Q_{1} & -Q_{3}\end{array}\right)$ of flow rate with the system $\left(450 / S_{2}\right)$.

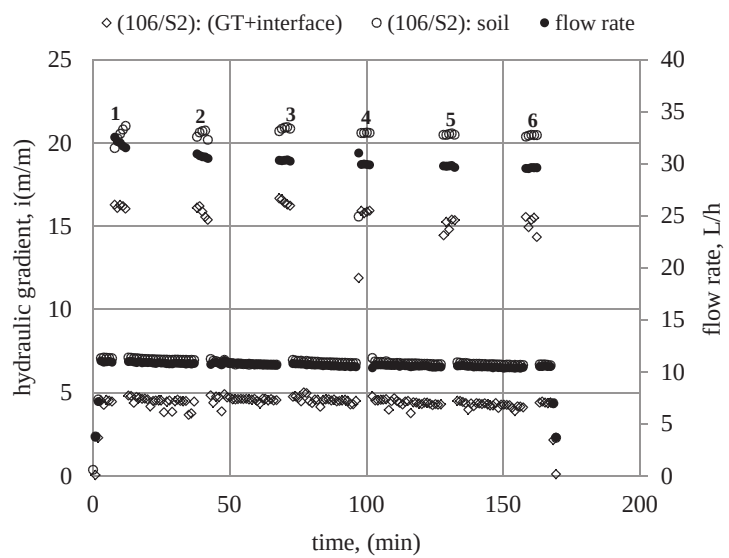

Figure 14. Hydraulic gradient responses to the imposed instantaneous changes $\left(\begin{array}{ll}Q_{1} & -Q_{3}\end{array}\right)$ of flow rate with the system $\left(106 / S_{2}\right)$.

obtained value of flow rates $-Q_{3}$ differ according to [GT-soil] systems, a dimensionless criterion, $\delta$, was defined to account for this difference. This criterion was obtained using a normalised value 


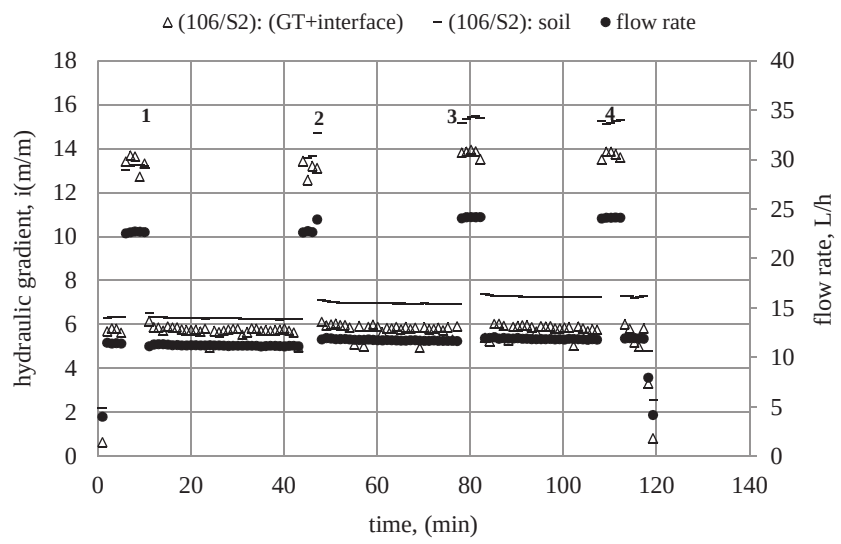

Figure 15. Hydraulic gradient responses to the imposed instantaneous changes $\left(Q_{1}{ }_{1} Q_{2}\right)$ of flow rate with the system $\left(106 / S_{2}\right)$.

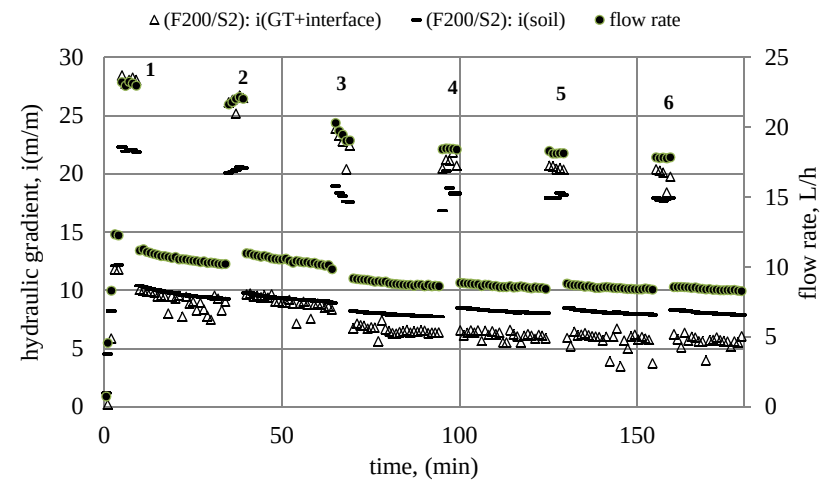

Figure 16. Hydraulic gradient responses to the imposed instantaneous changes $\left(\begin{array}{ll}Q_{1} & -Q_{2}\end{array}\right)$ of flow rate with the system (f200/S $\left.{ }_{2}\right)$.

Table 5. responses of hydraulic gradient to imposed instantaneous changes in flow rate, and corresponding values of criterion

$\delta$

\begin{tabular}{|c|c|c|c|c|c|c|c|c|c|c|c|c|}
\hline \multirow{2}{*}{$\begin{array}{l}\text { Geotextile } \\
\text { Soil }\end{array}$} & \multicolumn{4}{|c|}{106} & \multicolumn{4}{|c|}{405} & \multicolumn{4}{|c|}{ F200 } \\
\hline & & & & & & & & & & & & \\
\hline flow rate (l/h) & $\begin{array}{c}Q_{1} \\
11.0\end{array}$ & $\begin{array}{c}Q_{2} \\
23.5\end{array}$ & $\begin{array}{c}Q_{3} \\
30.4\end{array}$ & $\delta$ & $\begin{array}{c}Q_{1} \\
20.6\end{array}$ & $\begin{array}{c}Q_{2} \\
38.5\end{array}$ & $\begin{array}{c}Q_{3} \\
53.0\end{array}$ & $\delta$ & $\begin{array}{c}Q_{1} \\
8.33\end{array}$ & $\begin{array}{c}Q_{2} \\
19.8\end{array}$ & $\begin{array}{c}Q_{3} \\
22.3\end{array}$ & $\delta$ \\
\hline pressure drop (mbar) & $\Delta \mathrm{p} 1$ & $\Delta P_{2}$ & $\Delta P_{3}$ & & $\Delta P 1$ & $\Delta P_{2}$ & $\Delta P_{3}$ & & $\triangle P 1$ & $\Delta P_{2}$ & $\Delta P_{3}$ & \\
\hline Soil zone $\left(P_{2}-P_{3}\right)$ & 69.7 & 146 & $207^{3}$ & 1.40 & 40.06 & 78.09 & $86.7^{3}$ & 0.31 & 81.1 & $194^{2}$ & $245^{3}$ & 2.15 \\
\hline $\begin{array}{l}\text { (geotextile + interface } \\
\text { area) }\left(P_{3}-P_{4}\right)\end{array}$ & 3.11 & 8.49 & 9.83 & 0.69 & 4.97 & 10.0 & 14.8 & 1.36 & 1.37 & 5.58 & 6.74 & 2.90 \\
\hline Whole system $\left(P_{2}-P_{4}\right)$ & 72.8 & 154 & 216 & 1.37 & 45.0 & 88.1 & 101 & 0.42 & 82.5 & 199 & 252 & 2.18 \\
\hline
\end{tabular}

of the step perturbation of flow rate and the corresponding value of the normalised variation of the measured pressure drop. Thus, the change of pressure drop-( $\left(X P_{2}\right)$ induced by change of flow rate from $Q_{2}$ to $Q_{3}$ is normalised by the initial value of the pressure drop $\triangle \not P$ baseline). This normalised relative pressure drop is then divided by the corresponding normalised relative flow rate variation. The parameter obtained makes it possible to evaluate the behaviour of the [GT-soil] system undergoing an increase in pressure drop due to potential change in flow rate. The soil behaviour associated with each of the geotextiles was analysed during the instantaneous variations of flow rate, by calculating the following criterion: 


$$
\delta=\frac{\left.\frac{\left(\mathrm{P}_{3}-\Delta \mathrm{P}_{2}\right.}{\Delta \mathrm{P}_{1}}\right)}{\frac{\mathrm{Q}_{3}-\mathrm{Q}_{2}}{\mathrm{Q}_{1}}}
$$

where $\Delta P_{1}, \Delta P_{2}, \Delta P_{3}$ are the pressure drops (in mbar) recorded with the actual flow rates (L/h) $Q$ $Q_{2}$ and $Q_{3}$, respectively. This criterion was calculated for the differential pressures measured between taps $\left(P_{2}-P_{3}\right),\left(P_{3}-P_{4}\right)$ and $\left(P_{2}-P_{4}\right)$ and corresponding to different zones: soil, geotextile plus interfacial area and all-system, respectively. The calculated values are given in Table 5.

The lowest value of $\delta$ is observed in the soil layer of the draining system using GT 450, which means that it allows a greater flow rate of water associated to a lower pressure gradient in the soil, compared to the systems using other geotextiles. Geotextile 450 thus gives better soil drainage. It may also be noted that the value of $\delta$ in the region near this geotextile is relatively higher than that of the other bilayer GT (106). It means that geotextile 450 performs better on the filtration function than GT 106. Concerning the monolayer GT F200, the value of $\delta$ obtained at the geotextile and its interface is maximum. As a drawback, the permeability of the draining system using GT F200 is the lowest. The intrinsic properties of GT F200 (Section II-1) were rather in favour of it, as clogging was negligible in this case. In the situation of a draining system subjected to a long-term test with flow rate perturbations, this geotextile exhibits a tendency to clog as the reference flow rate $)_{1}$ (Qrogressively decreases.

Based on these findings, it is concluded that geotextile 450 offers the best compromise regarding the targeted application as it performs more efficiently on soil drainage while assuring filtration functions. Among the different tests performed and especially the flow tests of draining systems, the instantaneous flow variation tests associated with the use of the proposed criterion, $\delta$, allow a good discrimination of the three geotextiles tested in this work.

\section{Conclusion}

This study has used different experimental approaches to evaluate the performance of three types of geotextile (450, 106 and F200) for application as a filter for drainage and maintaining soil integrity. Tests on water permeation through the geotextiles at different pressures showed that the monolayer-geotex tile F200 provides a relatively great flow rate per unit area. The experimental testing at constant-pressure filtration of clay slurry through the geotextiles highlighted relatively less clogging with F200 which did not experience any decrease in flow rate. The structural parameters determined by image analysis at the start of this study were used to discuss the present results. The significantly lower gradient ratio (GR) values found in the contact area between the soil and geotextile F200 during a long-term flow indicate that there may be a risk of leaching with this geotextile. Based on the criteria established in the literature, the other GR values obtained with the two bilayer composites 450 and 106 cannot confirm the possible movement of fine grains through the geotextile openings. The values of the ratio of soil hydraulic conductivity to system hydraulic conductivity, which we used as an alternative criterion, indicates that no geotextile would be considered as clogged. The tests conducted by inducing sudden and periodic changes in flow rate and recording the pressure responses to these changes were analysed by calculating a new criterion developed here and designated $\delta$. This criterion is based on a ratio defined by the quotient of normalised relative pressure drop to normalised relative flow rate. The values of $\delta$ allow to discriminate between the three draining systems studied here. In particular, the examination of the values of $\delta$ obtained in different zones, i.e. soil, geotextile-plus-interfacial zone, and the whole draining system, shows that geotextile 450 outperforms the other geotextiles studied in this work as far as drainage and filtration are concerned. As expected, the study of intrinsic properties of geotextiles, including the study of flow seepage through them, does not allow predicting their behaviour in a draining system for example. The mechanisms of suffusion are well known to be complex and linked to a long history of the draining system. Thus long-term tests including variation of the flow seepage may serve as useful tools in this regard. It would be interesting to extend the use of the criterion $\delta$ 
proposed in this work to other studies so as to verify its ability to discriminate and rank geotextiles in terms of drainage and filtration functions.

\section{Acknowledgements}

The authors thank Professor Rajendra Chhabra of IITK (India) for proof-reading and correcting English.

\section{Disclosure statement}

No potential conflict of interest was reported by the authors.

\section{References}

Ahn, T. B., Cho, S. D., \& Yang, S. C. (2002). Stabilization of soil slope using geosynthetic mulching mat. Geotextiles and Geomembranes, 20, 135-146.

Akram, M. H., \& Gabr, M. A. (1997). Filtration of fly ash using nonwoven geotextiles: Effect of sample preparation technique and test method. Geotechnical Testing Journal, ASTM, 20(3), 263271.

ASTM D-5101-01. (2003, May). Standard test method for measuring the soil geotextile clogging potential by the gradient ratio (Vol. 04.13). Philadelphia, PA: Annual Book of ASTM Standards.

ASTM D5567-94 (2011). Standard Test Method for Hydraulic Conductivity Ratio (HCR) Testing of Soil/Geotextile Systems, ASTM International, West Conshohocken, PA. Retreived from www.astm.org

Austin, D., Mylnarek, J., \& Blond, E. (1997, March). Expanded anti-clogging criteria for woven filtration geotextiles. Proceedings of Geosynthetics '97, IFAI (pp. 1123-1144), Long Beach, CA.

Aydilek, A. H., \& Edil, T. B. (2003). Long-term filtration performance of nonwoven geotextile-sludge systems. Geosynthetics International, IFAI, 10(4), 836-847.

Aydilek, A. H., Oguz, S. H., \& Edil, T. B. (2002). Digital image analysis to determine pore opening size distribution of nonwoven geotextiles. Journal of Computing in Civil Engineering, 16(4), 280-290.

Bhatia, S. K., Moraille, J., \& Smith, J. L. (1998a). Performance of granular vs. geotextile filters in protecting cohesionless soils. In L. N. Reddi \& M. V. S. Bonala (Eds.), Filtration and drainage in geotechnical and geoenvironmental engineering, ASCE, geotechnical special publication 78 (pp. 1-29).

Bhatia, S. K., Moraille, J., \& Smith, J. L. (1998b). Performance of granular vs. geotextile filters in protecting cohesionless soils. Filtration and Drainage in Geotechnical/Geoenvironmental Engineering, 78, 1-29.

Christopher, B. R., \& Holtz, R. D. (1985). Geotextile Engineering manual FHWA-TS-86/203 (p. 1044). Washington, DC: US Federal Highway Administration.

Datta, U. (2007). Application of jute geotextiles. Journal of Natural Fibers, 4, 67-82.

Datye, K. R., \& Gor, V. N. (1994). Application of natural geotextiles and related products. Geotextiles and Geomembranes, 13, 371-388.

Fannin, R. J., Vaid, Y. P., \& Shi, Y. C. (1994). Filtration behavior of nonwoven geotextiles. Canadian Geotechnical Journal, 31, 555-563.

Fischer, G. R. (1994). The influence of fabric pore structure on the behavior of geotextile filters (p. 501; PhD dissertation). University of Washington, Seattle, WA.

Fischer, G. R., Mare, A. D., \& Holtz, R. D. (1999). Influence of procedural variables on the gradient ratio test. Geotechnical Testing Journal, 22(1), 22-31.

Franks, C. A., Aydilek, A. H., \& Davis, A. P. (2013). Modeling hydraulic conductivity of a geotextile filter during suspended solids accumulation. Geosynthetics International, 20, 332-343.

Gabr, M. A., \& Akram, M. H. (1996). Clogging and piping criteria for geotextile filters for fly ash. Proceedings of the 3rd International Symposium on Environmental Technology, San Diego, CA.

Giroud, J. P. (1996, May). Granular filters and geotextile filters. In J. Lafleur \& A. L. Rollin (Eds.), Proceedings of GeoFilters ‘96 (pp. 565-680). Montréal.

Giroud, J. P., Soderman, K. L., \& Badu-Tweneboah, K. (1997). Optimal configuration of a double liner system including a geomembrane liner and a composite liner. Geosynthetics International, 4(3-4), 373-389.

Indraratna, B., \& Locke, M. (2000, May). Analytical modeling and experimental verification of granular filter behavior. In W. Wolski \& J. Mlynarek (Eds.), Filters and Drainage in Geotechnical and Geoenvironmental Engineering (pp. 3-26). Rotterdam: Balkema.

John, N. W. M. (1987). Geotextiles. Glasgow: Blackie \& Sons Ltd.

Kenney, T. C., Chahal, R., Chiu, E., Ofoegbu, G. I., Omange, G. N., \& Ume, C. A. (1985). Controlling constriction size of granular filters. Canadian Geotechnical Journal, 2(1), 32-43.

Koerner and Ko. (1982). Laboratory studies on long term drainage capability of geotextiles. Proceedings of the Second International Conference on Geotextiles, 1, 91-96. 
Koerner, R. M., \& Robins, J. C. (1986). "In-situ stabilization of soil slopes using nailed geosynthetics", 3rd International Conference in Geotextiles (pp. 395-400). Vienna: Austria.

Koerner, R. M., Lord, A. E., \& Hsuan, Y. G. (1988). Long-term durability and ageing of geotextiles. Geotextiles and Geomembranes, 7, 147-158.

Lafleur, J., Francoeur, J., \& Faure, Y. H. (2002). Piping, bridging and blinding of geotextiles as evaluated from the gradient ratio test. Proceedings of the 7th International Conference on Geosynthetics (pp. 1069-1074). Nice, France.

Lekha, K. R. (2004). Field instrumentation and monitoring of soil erosion in coir geotextile stabilised slopes - A case study. Geotextiles and Geomembranes, 22, 399-413.

Locke, M., Indraratna, B., \& Adikari, G. (2001). Time-dependent particle transport through granular filters. Journal of Geotechnical and Geoenvironmental Engineering, 127(6), 521-529.

Mitchell, D. J., Barton, A. P., Fullen, M. A., Hocking, T. J., Zhi, W. B., \& Yi, Z. (2003). Field studies of the effects of jute geotextiles on runoff and erosion in Shropshire, UK. Soil Use and Management, 19, 182-184.

Mlynarek, J., Lafleur, J., Rollin, R., \& Lombard, G. (1993). Filtration opening size of geotextiles by hydrodynamic sieving. ASTM Geotechnical Testing Journal, 16(1), 61-69.

Mlynarek, J., \& Lombard, G. (1997, March). Significance of percent open area in design of woven geotextile filters. Proceedings of Geosynthetics '97, IFAI (pp. 1093-1107). Long Beach, CA.

Portelinha, F. H. M., Zornberg, J. G., \& Pimentel, V. (2014). Field performance of retaining walls reinforced with woven and nonwoven geotextiles. Geosynthetics International, 21, 270-284.

Rawal, A., \& Anandjiwala, R. D. (2007). Comparative study between needle punched nonwoven geotextile structures made from flax and polyester fibres. Geotextiles and Geomembranes, 25, 61-65.

Rawal, A., \& Saraswat, H. (2011a). Stabilization of soil using hybrid needle punched nonwoven geotextiles. Geotextiles and Geomembranes, 29, 197-200.

Rawal, A., \& Saraswat, H. (2011b). Pore size distribution of hybrid nonwoven geotextiles. Geotextiles and Geomembranes, 29, 363-367.

Rawal, A., \& Sayeed, M. M. A. (2013). Mechanical properties and damage analysis of jute/polypropylene hybrid nonwoven geotextiles. Geotextiles and Geomembranes, 37, 54-60.

Rigo, J. M., Mathieu, Y., Smolders, K., \& Alexandre, E. (1990). Inventory of current geotextile test methods and standards (p. 154). Brussels: Pub International Geotextile Society.

Rollin, A., \& Lombard, G. (1988). Mechanisms affecting long-term filtration behaviour of geotextiles. Geotextiles and Geomembranes, 7, 119-145.

Saha, P., Roy, D., Manna, S., Adhikari, B., Sen, R., \& Roy, S. (2012). Durability of trans esterified jute geotextiles. Geotextiles and Geomembranes, 35, 69-75.

Sanyal, T. (2017). Consolidation of Soft Soil with Prefabricated Vertical Jute Drain. In Jute Geotextiles and their Applications in Civil Engineering (pp. 117-125). Singapore: Springer.

Subaida, A., Chandrakaran, S., \& Sankar, N. (2009). Laboratory performance of unpaved roads reinforced with woven coir geotextiles. Geotextiles and Geomembranes, 27, 204-210.

Van Thao, L., Marot, D., Rochim, A., Bendahmane, F., \& Hong Hai, N. (2017). Suffusion susceptibility investigation by energy based method and statistical analysis. Canadian Geotechnical Journal. doi:10.1139/cgj-2017-0024

Veylon, G., Stoltz, G., Mériaux, P., Faure, Y. H., \& Touze-Foltz, N. (2016). Performance of geotextile filters after 18 years' service in drainage trenches. Geotextiles and Geomembranes, 44, 515-533.

Wayne, M. H., \& Koerner, R. M. (1993). Correlation between long term flow testing and current geotextile filtration design practice. Proceedings of Geosynthetics '93, IFAI (Vol. 1, pp. 501-517). Vancouver: British Columbia.

Wittman, L. (1979). The process of soil filtration. Its physics and the approach in engineering design. Proc., 7th European Conf. on Soil Mechanics-Design Parameters in Geotechnical Engineering (Vol. 1, pp. 303-310).

Zhang, Y. P., Liu, W. C., Shao, W. Y., \& Yang, Y. (2013). Experimental study on water permittivity of woven polypropylene geotextile under tension. Geotextiles and Geomembranes, 37, 10-15. 